Article

\title{
The Problem of Mismatch in Successful Cross-Sectoral Collaboration
}

\author{
Maritta Soininen \\ Department of Political Science, Stockholm University, 10691 Stockholm, Sweden; \\ E-Mail: maritta.soininen@statsvet.su.se; Tel.: +46-8-162641; Fax: +46-8-152529
}

Submitted: 31 May 2014 | In Revised Form: 9 September 2014 | Accepted: 29 September 2014 |

Published: 10 November 2014

\begin{abstract}
When facing the challenge of new global employment dynamics and the demand for the creation of economic growth and new jobs, joint cross-sectoral efforts to pool market and public sector resources promise to make the most of the complementary strengths, competencies and perspectives of different actors. The topic addressed here is the impact that management rationale-bureaucratic and entrepreneurial-has on cross-sectoral collaboration, and in particular how a mismatch in goals and norms between sectoral actors and the overall management rationale may affect joint efforts in terms of the capacity to recruit relevant actors and establish sustainable collaboration. The empirical findings, which are based on two cases of cross-sectoral co-operation - the EU programme EQUAL and the Swedish VINNVÄXT programme-suggest that management rationale is an important factor in accounting for success of cross-sectoral initiatives and that a mismatch risks undermining smooth co-operation and thereby policy delivery.
\end{abstract}

\section{Keywords}

cross-sectoral collaboration; management rationale; mismatch

\section{Issue}

This article is part of a regular issue of Politics and Governance, edited by Professor Andrej J. Zwitter (University of Groningen, The Netherlands) and Professor Amelia Hadfield (Canterbury Christ Church University, UK).

(C) 2014 by the author; licensee Cogitatio (Lisbon, Portugal). This article is licensed under a Creative Commons Attribution 4.0 International License (CC BY).

\section{Cross-Sectoral Collaboration for Economic Growth and the Creation of New Jobs}

In globalised labour markets, the creation of new jobs is a pressing issue that calls for new ways of formulating employment policies. Not only does globalisation entail redistribution of employment opportunities when national labour markets become part of transnational and regional job markets, but governments also find their powers limited in regulating employment. Public sector experiences alone and hierarchical "one size fits all" policies do not appear to be sufficient for meeting these challenges. The failure of a market solution is equally obvious. In fact, the dysfunctions of supposedly self-regulating markets seem to have caused the rapid job losses of past decades. When publicprivate and global interdependencies appear as all the more salient, new forms of pooling resources and "know how" from the market and the public sector are a logical response to labour market complexity.

There are particularly high expectations among policymakers and politicians with regard to cross-sectoral policy making. Making the most of the complementary strengths of sectoral actors is expected to guarantee innovative and sustainable solutions to problems. Paradoxically, however, some research findings indicate that same-sector collaboration may be far more successful than working with actors from different sectors. For example, same-sector partners cooperate in a more effective way, leading to successful policy outcomes-they simply seem to get along better with each other (Andrews \& Entwistle, 2010, p. 689). Managing the differences between actors with divergent sectoral backgrounds is, therefore, not only a challenge for the individual organisations involved in participation, but also for the overall management of the joint effort. 
The question that this paper addresses is the role of the management rationale in facilitating and impeding cross-sectoral collaboration, and, more precisely, how the mismatch between the management rationale and the sectoral orientations of the actors affects vital conditions for collaboration. This mismatch is defined as a situation where the overall management rationale and an actor's orientation are guided by different sector logics.

The aim of the discussion below is to advance the scholarly debate about conditions for successful crosssectoral policy co-operation. The first section of the paper contextualises the research question of management rationale and mismatch in current scholarly debates on management/administrative styles. This is followed by a description of the empirical cases and data. The third part of the paper consists of the presentation of two case studies, mapping working processes in two instances of cross-sectoral collaboration. The fourth section summaries and analyses the main empirical findings.

\section{Cross-Sectoral Collaboration for Employment Creation}

Research shows that the use of solutions inspired by the private sector, such as outsourcing, contracting out and quasi-market models for employment creation in Australia, Holland and Denmark, have not resulted in higher efficiency and innovation or less bureaucracy, in comparison with public sector solutions (Bredgaard \& Larsen, 2011). Instead, an increasingly popular alternative, which is exemplified by the EU employment strategy, Boston's workforce system in the U.S. (Herranz, 2007) and the Swedish policy for economic growth and jobs, involves various hybrid forms of joint public-private co-operation. These are seen as a promising approach to employment creation, workforce development and integration of socio-economically marginalised groups in the labour market.

In theory, cross-sectoral partnerships not only "enable public agencies to tackle social problems more effectively by unlocking the benefits of comparative advantage" (Andrews \& Entwistle, 2010, p. 680), but by enhancing reciprocity and mutual learning, they also build future cross-sectoral problem solving capacity (Innes \& Booher, 2003). Pooling resources helps to enhance innovation potential by making the most of complementary strengths and synergy effects of diverse competencies and knowledge on the part of different sectoral actors. Sometimes this form of new public governance (NPG) is also labelled "good governance", since it involves using networks and partnerships between governments, business corporations and civil society associations to govern society in a more effective and legitimate way by including a wide range of societal stakeholders in policymaking and implementation (Pollitt \& Bouckaert, 2011, pp. 21-22).

For an individual stakeholder, the incentive for par- ticipation in a joint project can be the potential gains and costs related to participation, and the action is "a result of choices based on calculated self-interest" (March \& Olsen, 1984, p. 734). Collaboration is used instrumentally, for example as a way of acquiring new competencies or of gaining access to new economic resources. Alternatively, beyond the realm of the rational intentions, a stakeholder may be driven primarily by role expectations and shared norms in its organisational milieu, i.e. by what is understood as an 'appropriate' way of acting (March \& Olsen, 2006, p. 289). This might, for example, involve living up to expectations of market efficiency or allowing actions to be guided by public sector rule of accountability.

Several factors may nevertheless undermine the benefits of cross-sectoral collaboration aiming at innovative and cost-efficient approaches to job creation. Fear on the part of an actor of being co-opted and losing legitimacy may effectively prevent it from getting involved in joint action (Hendriks, 2009), as may the prospect of losing rather than winning economic and human resources (Sörensen \& Torfing, 2007). In addition, participation may be felt to be somehow inappropriate if it goes against the role expectations and norms that the actor follows.

In addition, the very mix of divergent sector backgrounds of participating actors constitutes a specific challenge for cross-sectoral co-operation, sometimes creating conditions that can jeopardise expected positive outcomes. Since criteria of success differ among corporate, government and civil society organisations, it may even be a challenge to establish shared outcome criteria for successful collaboration (Selsky \& Parker, 2005, p. 864).

It is, then, reasonable to argue that the overall management of a cross-sectoral initiative appears to be a key factor in facilitating a collaborative process. Therefore, the research question here addresses the role of management rationale in cross-sectoral policymaking, and especially the possible effects of a mismatch between the public/private sector orientations of participating organisations, with their respective values, norms and prescribed administrative processes on the one hand, and the overall management rationale of the joint cross-collaboration on the other.

Indeed, network management research has been criticised for not fully recognising the importance of sectoral differences and instead tending to assume that organisations behave in a similar manner within a network, regardless of whether they are governmental, non-profit or business organisations (Herranz, 2007, p. 26). One possible explanation may be found in the widely shared prescriptive and descriptive understandings of recent organisational developments.

When organisations are conceptualised as open systems in continuous interaction with other organisations in order to exchange resources, personnel and 
ideas (DiMaggio, 1988; Scott, 1995, 2003), the increased popularity of NPM during past decades, together with opting out and privatisation of public sector competencies and tasks, can be seen as resulting in a situation where business companies and public sector bodies become increasingly "multiply embedded", as they adopt a "role or function traditionally associated with another sector" (Selsky \& Parker, 2005, pp. 851-853). Since learning and borrowing from organisations in sectors other than one's own becomes essential, this eventually gives rise to blurred roles and functions. The idea of converting sector logics, however, easily overshadows the fact that public and private sectors still display fundamental differences as different organisational fields and that when actors with different sector backgrounds focus on an issue, they "are likely to think about it differently, to be motivated by different goals, and to use different approaches" (Selsky \& Parker 2005, p. 851). Even though all organisations are "public" in a sense that they are to a varying extent influenced by political authority (Bozeman \& Bretschneider, 1994), it is still useful to make an analytical distinction between the public and private sectors.

As organisational fields, the public and market sectors each display their own rationale and ideas of what is an appropriate way to act, what are reasonable solutions, and how success should be measured (cp. March \& Olsen, 1984, 2006). Private companies operating in the market sector are traditionally associated with the entrepreneurial orientation embodied in the main goal of profit maximising and vales of customer and market focus. The public sector, represented by governments and public sector agencies but also including such public bodies as state-owned universities and research institutes, normally operates instead through hierarchically organised processes so as to follow accountability rules in implementing government policies.

Given the differences between the public and private sectors in what constitute their main goals and organisational processes (Herranz, 2010), it is not surprising that cross-sectoral collaboration, while at best generating new innovative products and solutions to societal problems, also faces greater challenges than, for example, same-sector public-public partnerships. According to a study of effectiveness, efficiency and equity in a large number of UK partnerships, publicpublic partnerships perform best on effectiveness, while cross-sectoral public-private partnerships are less effective (Andrews \& Entwistle, 2010, p. 689). What, then, explains this result? Researchers argue that "public-public partnerships may work on a more promising agenda or else just get along better than the alternatives" (Andrews \& Entwistle, 2010, p. 694). Sharing sector-specific norms and understandings of appropriate ways of acting seems to make it easier for the organisations to succeed in their collaboration.

To meet these challenges of divergent appropriate- ness logics, knowledge and experiences, which are conducive to cross-sectoral co-operation and the very reason it appears so attractive in terms of high potential for innovation, the overall management plays a central role in facilitating smooth administrative processes. As research shows, sector rationales-bureaucratic and entrepreneurial, respectively-are not only embodied at the organisational level but also inform the management approach at the level of collaboration (Herranz, 2007, 2010). Herranz notes knowledge of "how different types of managerial co-ordination relate to network outcomes is still relatively limited" (Herranz, 2010, p. 447).

At present, the bulk of scholarly debate on public sector reforms focuses on three main models for public sector management/administration: New Public Governance (NPG) as a distinctly different model from New Public Management (NPM) and what is labelled the Neo-Weberian State (NWS) (Pollitt \& Bouckaert, 2011, pp. 21-22). At the heart of the debate is an intense dispute over the term "bureaucracy", which supporters of NPM tend to associate with the defects of public sector management, while promoting as a solution the entrepreneurial management ideal inspired by market sector values and ideology, and which is often defined in opposition to what is seen as "impersonal, procedural, hierarchical and technical organization of the Weberian bureau" (du Gay, 2000, p. 6). Critics see a risk for simplistic descriptions of bureaucratic forms of organisation. In contrast to picturing bureaucracy as a static model, "a single, universal bureaucratic regime of public administration", it is instead a "many-sided, evolving, diversified organizational device" (du Gay, 2005, p. 3), varying as a result of divergent constitutional solutions.

While keeping in the mind the real-life complexity and variation in different administrative solutions, it will still be necessary, in order to examine the effects of the mismatch between participants' sector orientations and the management rationale, to identity the core characteristics of the two main ways of managing cross-sectoral collaboration: the bureaucratic management rationale and the entrepreneurial one.

According to Goodsell, although bureaux/state administrations vary in make-up, they still most likely share the "classic Weberian characteristics of graded hierarchy, formal rules, specialized tasks, written files, and full-time, trained salaried, career employees" and embody a vertical line of authority in order to assure external control and accountability (Goodsell, 2005, p. 18). In other words, these traits can be said to describe the classical Weberian bureaucratic management style. Following Pollitt and Bouckaert, we identity central traits for the "market-type mechanism", i.e., the use of performance indicators, targets, competitive contracts, "quasi-markets", which also define the entrepreneurial management rationale as a distinct form, separate from the co-ordination mechanism of the Weberian bureaucratic style that exercises authority through a 
state-centred, disciplined hierarchy (Pollitt \& Bouckaert, 2011, p. 22)

Guided by the preceding ideas of administrative/management solutions and Herranz's distinction between the bureaucratic management style that emphases "formalised inter-organisational relations based on contracts or standardised procedures and the entrepreneurial management style", inspired the by ideals of a private sector organisation, in his model of Strategic Orientation Values Sets (Herranz, 2007, p. $10)$, we summarise the central elements of each management rationale in Table 1.

While the ideology of bureaucratic management is based on legislative order, the entrepreneurial style is recognised by its efficiency and market focus, with economic value maximisation as its vital goal. For the bureaucratic rationale, embodying the Weberian ideal, the main objective is instead to implement government policies and to be accountable for that.

How, then, should the control of cross-sectoral collaboration ideally be formed? Here, the two models offer different solutions: the bureaucratic rationale prescribes centralised rule-based control, while the entrepreneurial one favours quasi-centralised control, thus providing more leeway to the collaborators. Structure, one of the two remaining parameters, is closely related to control and refers either to a hierarchical process or to a process relying on the delegation of powers to those participating in the joint action. Finally, decision-making tends, in the case of bureaucratic management rationale, to follow a top-down process as the entrepreneurial co-ordination exhibits a flexible and ad hoc-based way of taking decisions, ultimately dictated by the incentives of value maximisation. Thus, the entrepreneurial rationale places the emphasis on management by incentives related to performance goals and grants the cross-sectoral collaboration and the sectoral actors involved broad powers in designing the joint activities. The bureaucratic rationale largely entails a different form of management praxis, with its top-down co-ordination based on formalised procedures, written contracts and systems for accountability reports in relation to the implementation of policy objectives (Herranz, 2007, 2010).

Herranz's empirical findings show that the choice of management style makes a difference: bureaucratic style is associated with low performance, both at the level of the participating actor and at the level of multisectoral collaboration, while entrepreneurial management correlates with moderate to high performance. A main conclusion is that more attention needs to be paid to the multi-sectoral mix of collaborators in relation to the co-ordination style when explaining collaborative outcomes (Herranz, 2010, pp. 456-457). Given that management rationale appears to be such an important factor in explaining successful cross-sectoral collaboration, it is not surprising that the topic has, ac- cording to critics, received too little attention (Selsky \& Parker, 2005, p. 866).

We address, more precisely, the question of what impact the mismatch between management rationale and the different sector orientations of participating and potentially participating actors has on the performance of cross-sectoral collaboration in terms of its capacity to recruit relevant actors and create sustainable and successful working processes.

To conclude the theory section, Table 2 illustrates the hypotheses of mismatch between alternative management rationales and sector actor orientations representing divergent values, processes and strategic goals. In the context of this paper, we use the term mismatch to describe a situation where the overall management rationale and an actor's orientation are guided by different sector logics.

Previous research shows that a same-sector publicpublic background of actors has a positive impact on effectiveness in terms of "getting along better". Our questions is whether this result of the positive effects of matching backgrounds-and the negative effects of non-matching orientations-is also valid for the relationship between management rationale and individual sectoral actors and, if so, whether this correlation holds regardless of the kind of management rationalebureaucratic or entrepreneurial.

Table 1. Two management rationales.

\begin{tabular}{lll}
\hline & Bureaucratic & Entrepreneurial \\
\hline Goals & $\begin{array}{l}\text { Implementing } \\
\text { government policies, } \\
\text { accountability }\end{array}$ & $\begin{array}{l}\text { Value/profit } \\
\text { maximisation }\end{array}$ \\
Ideology & $\begin{array}{l}\text { Legislative order/state } \\
\text { focus }\end{array}$ & $\begin{array}{l}\text { Market/efficiency } \\
\text { focus }\end{array}$ \\
Control & $\begin{array}{l}\text { Centralised/ } \\
\text { rule-based }\end{array}$ & $\begin{array}{l}\text { Quasi-centralised/ } \\
\text { incentives related to } \\
\text { performance goals }\end{array}$ \\
Structure & Hierarchical & $\begin{array}{l}\text { Quasi-autonomous/ } \\
\text { delegation }\end{array}$ \\
Decision- & Top-down in & $\begin{array}{l}\text { Ad-hoc dictated } \\
\text { brocess value }\end{array}$ \\
& $\begin{array}{l}\text { accordance with } \\
\text { government policies }\end{array}$ & maximisation \\
\hline
\end{tabular}

Table 2. Management rationale and sector orientation.

\begin{tabular}{llll}
\hline & & Bureaucratic & Entrepreneurial \\
\hline \multirow{3}{*}{$\begin{array}{l}\text { Sector } \\
\text { orientation }\end{array}$} & $\begin{array}{l}\text { Public } \\
\text { body }\end{array}$ & Match & Mismatch \\
& $\begin{array}{l}\text { Private } \\
\text { company }\end{array}$ & Mismatch & Match \\
\hline
\end{tabular}




\section{Method and Data}

In order to examine empirically the question of mismatch and it effects, we have conducted qualitative case studies of two instances of cross-sectoral collaboration by scrutinising their structures, processes and goals. The case selection is designed so that the two cases-the EU programme EQUAL and the Swedish triple helix programme VINNVÄXT, together include the two different management rationales-bureaucratic and entrepreneurial-thereby enabling us to explore the impact of mismatch, regardless of type of management rationale. These two instances of collaboration are not viewed here as two equivalent sets of observations but rather as two complex configurations of events and structures (Ragin, 1997). By relating management rationale to how they perform in terms of recruiting relevant sectoral actors to appropriate joint action, we can shed further light on the broader puzzle of how the in-built mismatch between the management rationale and sector orientations of actors influences performance in joint collaboration.

The EU programme EQUAL and the Swedish triple helix programme VINNVÄXT are in many ways distinctly different: the first one operating within the multilevel EU context, the second one within the Swedish regional context. This gives us the advantage of being able to empirically explore the effects of mismatch in vastly different contexts of governance. At the EU level, the EQUAL programme is a component of the European Employment Strategy (EES), while VINNVÄXT, which is a part of the Swedish Regional Development and Economic Growth Policy, is a government initiative. Both programmes enjoy strong political support. The EU, with a limited legislative mandate, needs to apply new forms of policy making such as allocating structural funds to support public-private partnerships in the development of new ways of implementing employment policies (European Commission, 2009):

...the top challenge for the EU today must be to prevent high levels of unemployment, to boost job creation (...) This will only be achieved with strong co-operation between all the stakeholders, better policy coordination and mutual learning...

In the Swedish case, long-standing corporatist policy making, in particular in labour market policy, paves the way for novel measures in innovation and employment creation. This legacy supports consultation between politicians, the public administration and organised interests at the local level, involving a broad range of local business and public interests in decision making (Hall \& Montin, 2007, p. 2II). The fundamental notion of the Swedish triple helix programme that aims to create new jobs by enhancing co-operation horizontally between public sector and business actors, is defined as (Westerberg, 2009, p. 51):

A very decisive interaction is taking place in the innovation system between three groups of actorsindustry, academia and the public sector.

The empirical materials consist of evaluation reports, which offer detailed descriptions of collaboration and provide rich and focused accounts of processes and objectives in each case. For the EQUAL programme, the EU has commissioned a number of evaluations conducted by major international consultancy companies, such as Bernard Brunhes International and ECONOMIX Research \& Consulting. In the case of the Swedish triple helix VINNVÄXT, the government has produced several evaluation reports. Relying on these secondary sources-in many cases comprehensive investigations-for the empirical analyses is to some extent a methodological limitation, as these investigations were originally conducted for purposes other than to examine the question of the mismatch. However, the choice of material provides access to empirical data that would otherwise be very costly and, to some extent, perhaps even very difficult to gain access to. The evaluation reports not only offer critical descriptions of these two empirical cases. They are also based on reliable, high quality empirical research.

The final "EU-Wide Evaluation Report" covers activities of EQUAL between 2001 and 2006 and is based on national evaluation reports, case studies of transnational partnerships, interviews with managing authorities in member states, participant observation and surveys among participants. The 335-page report covers the strategies in EQUAL as well as "management and implementation systems" (Bernard Bruhnes International, 2006, xii). Similarly, the two others evaluations, Synthesis/EU10 Member States, and Synthesis/EUR-15 Member States are each based on national evaluations studies and additional interviews with national evaluators and representatives of managing authorities. The aim of the EU Commission is to use of this documentation in the "preparation, management, monitoring and evaluation of future programmes, and to facilitate the postevaluation of the programme" (Economix, Research \& Consulting, 2009, vii). The empirical data for the Swedish case consists of a study VR 2009:19 and VR 2008:08 conducted by VINNOVA (Swedish Governmental Agency for Innovation Systems), based on 52 interviews with participants in eight VINNVÄXT processes. In addition, the empirical materials include a research report $R$ 2004:10 by NUTEK (Swedish Agency for Economic and Regional Growth) on how small companies collaborate with other actors, based on a survey including 5,000 firms.

\section{Tools for Developing European Employment Strategy}

Enforcement, management and persuasion are three 
central implementation strategies in the EU Social Policy, (Hartlapp, 2007), while common guidelines and systems of standards and indicators are employed to create shared "EU knowledge" (Mosher \& Trubek, 2003) and even a "hegemonic discourse" (Haahr, 2004). Voluntary policy co-ordination through public-private collaboration, albeit under the "shadow of the hierarchy" of the Commission (Smismans, 2008), is a wellestablished method.

In its directive C2000 853 Establishing the guidelines for the Community Initiative EQUAL, the Commission establishes the key principles of EQUAL crosssectoral collaboration: in order for the European Employment Strategy (EES) to be fully effective, it must be translated into action at the local and regional levels, in urban and rural districts-i.e., in contexts that are able to generate local co-operation (European Commission, 2000). Therefore, the EU allocates structural funds to support cross-sectoral partnership, the goal of which is to promote policy learning across sectors and levels of governance. The main goal of EQUAL is to provide a "testing ground for the development and dissemination of new ways of delivering employment policies" (European Commission, 2000), and thereby helping to implement the main goals of the EES (Ramboll, Euréval, \& SEOR, 2010): to create conditions for a socially inclusive labour market and high levels of employment. For the period 2000-2006, the EU funded EQUAL with 3.2 billion euros, which was supplemented with national co-funding of over 2.2 billion euros. During the period 2007-2013, the European Social Fund disseminated the lessons learned from EQUAL by using approximately 3 billion euros for transnational cross-sectoral co-operation.

EQUAL guidelines state that public-private partnerships have a good potential for promoting "joint efforts" and "transfer of experience and good practice" in the main areas of the EES. Thus, innovation, mainstreaming, empowerment and transnationality are the principles that inform the workings of the development partnerships. In order to qualify for funding, a partnership needs to bring together relevant and central actors on a geographical or sectoral level, including public bodies, business actors, social partners and civil society organisations. The role of public bodies in the collaboration is to ensure a good correspondence between the work that is carried out through partnerships and the development needs of the territory, so that the innovative employment measures can be disseminated horizontally to organisations in the same field and vertically to regional and national policy makers and mainstreamed in regular employment policies (European Commission, 2000).

Our first question here is how the EQUAL programme performs in terms of organising the working process. What kind of management rationale characterised the programme, and which values, principles and processes constitute the framework for managing the partnerships?

\subsection{Management Processes-Experiences of Bureaucratic Rationale}

During 2000-2006, EQUAL funded 1,352 cross-sector partnerships. The evaluation reports offer detailed descriptions of the ideology of the programme, its goals in terms of accountability or value maximisation, and its structure in terms of being hierarchical or quasiautonomous.

Following the two leading programme ideasinnovation and empowerment-the EQUAL guidelines recommend "democratic", or at least participatory governance, mechanisms and also that "those involved in the implementation of activities should also take part in decision making" (Bernard Bruhnes International, 2006, p. 57), which suggests inclusive and perhaps even empowering decision making processes for public and private sectoral actors in the partnerships. During the first round of the partnerships, however, such "fully participative mechanisms" were criticised for being cumbersome and less sustainable (Bernard Bruhnes International, 2006, pp. 65-68) and were successively replaced with processes of increased streamlining, centralisation and specialisation in decision making. The decision making processes came to resemble a classic hierarchical model.

How did the actors involved experience the EQUAL management rationale? Indeed, several sectoral actors and, in particular, the beneficiaries of measures, found it difficult to follow the intricacies of project management, which, according to evaluators, may have had "a disempowering rather than an empowering effect" (Bernard Bruhnes International, 2006, p. 67). The programme terminology was criticised for being highly complex and difficult to grasp. Sometimes it required conscious efforts on the part of lead partners to explain it, and participants that were more familiar with EU programmes helped the less experienced ones. Several evaluation reports brought up the problem of what could be labelled "bureaucratic overload" (Economix, Research \& Consulting, 2009, p. 7):

During the interviews with the Managing Authorities and the National Support Structures it became clear that a heavy administrative system represented a major problem for many new Member States. Not only was the reporting time consuming for DPs, but also for Managing Authorities and National Support Structures as they concentrated their resources on checking financial claims for compliance and eligibility, and formal completeness of monitoring reports.

Further (Economix, Research \& Consulting, 2009, p. 10):

Evaluators as well as Managing Authorities themselves perceived the administrative processes as be- 
ing not efficient from the Programme's implementation view point...Administrative requirements at DP level (including technical and financial reporting, application of public procurement rules) were consuming important time and human resources.

However, there was some improvement in the EQUAL management routines later in the programme period (Bernard Brunhes Internacional, 2009, p. 34):

Monitoring systems used by Member States evolved throughout the life-cycle of EQUAL. While in round 1 they were classified as "highly bureaucratic" and "with too much focus on financial data", in round 2, monitoring systems were simplified and improved.

In short, EQUAL represents many of the traits that signify cross-sector collaboration with a bureaucratic management rationale. There was intense use of formalised procedures for rule following involving written contracts, standardised information collection and a comprehensive system for reporting. The evaluations reveal that ESF and its national and regional bodies emphasise formalised inter-organisational relations for EQUAL partnerships, based on contracts covering planned activities and use of economic resources. The regular monitoring activities include documented procedures for controlling partnership activities and their results, economic transactions and daily log/time reports for those working in a partnership, under the supervision of the representatives for regional and local ESF bodies.

In order to receive continuous funding during its lifetime, a partnership needed to produce approved accountability reports on a regular basis that followed a detailed and standardised model. In brief, it is possible to conclude that the question of accountability appears to be a more central goal for the Commission than value maximisation. What was initially based on ideas of innovative and voluntary policy learning and co-ordination between business actors and public bodies in the EQUAL partnerships was transformed by means of contracts, specific project terminology and regularly monitoring of activities with the help of fiscal and activity reports into a process that was criticised for its lack of effectiveness.

With the comprehensive system of accountability reports follows a structure that is relatively hierarchical, with only limited leeway for activities other than those planned, budgeted and approved in advance. Control over the activities was centralised, with little, if any, ad hoc decision-making. To sum up, several of these factors indicate that the EQUAL management represented a hierarchical management rationale. Peters identifies as one of the four possible problems of bureaucracy "an excessive action" on part of the institution (Peters, 2010, p. 267). In the case of the EQUAL's management rationale, the critics would probably agree on such a verdict.

\subsection{Mismatch-Quest for Business Actors}

The success of cross-sector collaboration depends on its capacity to attract and recruit relevant public and private organisations. When assessing the outcome of EQUAL, an important question is whether the partnerships, in accordance with the programme guidelines, succeed in engaging smaller and larger organisations as well as public bodies and private sectoral actors.

First, which actors have qualified for EQUAL membership? The results (Bernard Bruhnes International, 2006) show that public authorities and education and training organisations are the most frequent lead partners, 46 per cent in total, while business actors and social partners participate more often merely as "regular" partners. All in all, private enterprises comprise only 12 per cent of the sectoral actors involved, and their share is even lower among lead partners: only 9 per cent. It is, thus, hardly surprising that several national evaluators expressed criticism concerning the low level of involvement of business actors in EQUAL (Bernard Brunhes Internacional, 2009, p. 8):

National evaluators often criticized the weak involvement of private companies. A higher involvement would have been useful, as it would have created a deeper understanding of the problem as well as it would have helped searching for possible solutions, as argued for instance by the LV evaluator. The EU-wide final evaluation report of 2006 showed that also in the old Member States the involvement of the private sector was considered as low and difficulties in attracting the private sector to engage in projects dealing with inequalities and discrimination were named.

In addition, it became apparent that it was difficult for companies to maintain participation throughout a partnership life cycle (Bernard Bruhnes International, 2006, pp. 57-59). More often, they terminated participation in the middle of the partnership period. In sum, the picture is very much one of public sector bodies being the relevant and strategic key players. When scrutinising "partnership composition and inclusiveness", the evaluation report expresses concerns over whether the partnerships in reality meet the requirements of "large institutional representation" and "professionalism and expertise", thereby "ensuring the coverage of the full range of required skills".

The evaluation reports do not provide any information about the motives behind the participation of business companies nor about their reasons for not joining. However, the management rationale of EQUAL, with its normative framework, is far from an entrepreneurial market rationale stressing values of efficiency 
and cost-effectiveness. This may explain the limited participation of private companies.

Whether we try to account for the choice to participate or not on the part of a company based on rational actor explanations in terms of interest maximisation or based on a picture of business actors as guided by norms and values embedded in the market sector orientation, it is not difficult to see why EQUAL failed to attract them. If companies are conceptualised as being maximisers of their economic utilities, we can assume that they would be very careful about how they invest their limited resources and thus be reluctant to deal with the extensive and time consuming administrative routines of EQUAL. Importantly, the programme did not promise any immediate measurable outcomes, only long-term deliverables in terms of "developing innovative measures for inclusive labour marker policies".

The alternative explanation focuses on differences in appropriateness norms between the management rationale of EQUAL and the sector orientation of the business companies. There is obviously a gap between EQUAL's ideal of empowering participatory democratic process, though later implemented as a top-down command and control process, and the private sector understanding of what an appropriate way of implementing a project is as follows: measurable economic feedback on time and human resources invested in collaboration. The explanation for the reluctance on part of the companies to participate in EQUAL would then be the difference between the norms the EQUAL management rationale prescribes and the role expectations and norms that business actors embody.

Public sector organisations will likely find it easier to conform to the EQUAL management routines. The time consuming administrative procedures, requiring continuous documenting of activities and finances, are simply more familiar to them, as they coincide with public sector logic. So too, EQUAL's top-down decisionmaking process is easier for public sectoral actors to identify with and to perceive as reasonable and appropriate. However, this time the management rationale is not state-focused but EU-centred. While the EQUAL objectives stressed innovation and creativity and the programme aimed at policy learning across sectors and development, as well as dissemination of new ways of delivering employment policies, its management rationale, paradoxically, expressed values of hierarchical and detailed management to bring about this creativity.

\section{Triple Helix for Swedish Regional Development for Economic Growth}

The Swedish Regional Development and Economic Growth Policy is based on collaboration between public agencies, business actors and interest organisations. The Governmental Agency for Innovation Systems,
VINNOVA, and the Agency for Economic and Regional Growth, Tillväxtverket, are a result of the Swedish legacy of supporting close co-operation between market actors and public bodies. VINNOVA's main task is to promote sustainable economic growth by funding needs-driven research and the development of effective innovation systems. It initiates, stimulates and manages joint activities between public and private actors in order to increase economic growth and to "work to achieve more enterprises, growing enterprises and sustainable, competitive business and industry throughout Sweden" (Westerberg, 2009). Historically, Swedish governments have been supportive of larger export industries, while the situation for small business is somewhat different. The role of companies has also changed and in globalised markets, the traditional corporate responsibility for local employment has been replaced by more general concerns for national and global issues.

According to VINNOVA, in a modern society aiming at economic development and job creation, other alliances must come about to replace the old bonds that held together the local factory areas (Westerberg, 2009), now building on regional enlargement, as well as on geographical and professional mobility. Demands for costeffective but flexible ways of offering the markets new products, new services and new jobs thus put pressure on business companies to develop alliances so that they can share investments that open up access to new markets.

\subsection{Management Rationale of the Triple Helix VINNVÄXT Programme}

The VINNOVA programme VINNVÄXT, Regional Growth through Dynamic Innovation Systems, aims to promote sustainable growth by developing globally competitive research and innovation environments in specific growth fields (Westerberg, 2009, p. 7). This triple helix programme is based on mutual dependence between actors from the public and private sectors. Private companies need the public sector for infrastructure in terms of regulation and service, and research institutes/universities for training and research. The public sector is dependent on a competitive industry and research in order to be able to secure an economically sustainable society.

How is VINNVÄXT managed? Under the auspices of the government agency, the corner stone of the programme is voluntary regional co-operation between research institutes, private sectoral actors and public agencies, based on mutual agreements. As regards the structure of the programme, it takes the form of competition between regional initiatives which guarantees a quasi-autonomous position for the competing units. The winning projects receive funding up to one million euro per year for a period of ten years. In addition, they are offered so-called process support, which takes 
the form of seminars, training and experience-sharing (Westerberg, 2009, p. 12). One of the most central criteria is that a collaboration is considered to have growth potential and can be expected to be internationally competitive in its field within ten years (Westerberg, 2009). From its inception in 2001 until 2012, there have been 12 winners. While some of the joint projects test new ideas and create arenas for supporting learning, others are oriented towards commercial goals.

Value maximisation is seen as the main objective of VINNVÄXT, and incentives are directly related to performance goals. In sum, the management rationale of VINNVÄXT represents a highly entrepreneurial orientation. Evaluation results show that there is good support in regions for triple helix partnerships. The report also notes that different actor categories may have distinctly different goals and that mutual understanding is required (Westerberg, 2009). It, therefore, recommends learning by "fighting" as a method for increasing reciprocity between the partners. In short, cross-sectoral co-operation is not expected to be without difficulties.

\subsection{What Makes Small Companies Seek Collaboration?}

A central question is whether business actors are interested in the triple helix government initiative. What characterises those business actors that participate in cross-sectoral collaboration: is it a last desperate resort for a business company that is struggling to survive? Or, is it rather good economic growth in a company that encourages it to expand the opportunity structure through engagement in triple helix? Is partnering a component in a company's entrepreneurial agenda of risk taking? Or, is the wish to rely on other actors motivated by a lack of other entrepreneurial initiatives? And furthermore, do companies collaborate as a part of general investment in competence development, accompanied by spending on the education of employees? Or, is it a way out for market actors that cannot afford a development budget of their own?

A survey by NUTEK (Ylinenpää \& Westerberg, 2004, p. 10) of 5,000 Swedish firms with 5-50 employees, complemented with their annual economic reports, on how Swedish companies collaborate in general, and with public partners in particular, provides some answers to these questions. Understanding small companies as isolated from rest of society turns out to give a false picture of the private sector, according to the report. While 8 per cent of companies collaborate with all three triple helix actor categories, i.e., business actors, public actors and academic research institutes/universities, around 15 per cent are engaged in a more regular entrepreneurial manner in co-operation with other companies, as well as public bodies. The largest proportion of small Swedish companies, 37 per cent, only cooperates with other market sector actors. Finally, 27 per cent of business actors do not co- operate at all. In short, although co-operation with other market actors is the most popular form, collaboration with organisations representing alternate sector ideologies and norms-either the public sector or the research/academic world-was not that unusual.

The most often cited reason for cooperating was the search for new knowledge (Ylinenpää \& Westerberg, 2004 , p. 10). This openness was also demonstrated by the correlation between "entrepreneurial behaviour" operationalised as a company's degree of innovativeness, pro-activeness and risk propensity-and degree of co-operation with actors from other sectors: the higher a company's score on entrepreneurial behaviour, the more likely that it cooperates with both public agencies and research institutes. In brief, business actors that are willing to take risks and are innovative often actively seek new cross-sectoral collaboration opportunities.

A company's propensity to co-operate with other organisations is also positively correlated with its tendency to invest in internal competence development, either by providing employees with further education or by employing more academics. A factor that appears to be particularly important was the share of academics among the employees. In companies that have no partners, the share of employees with a university degree is around 11 per cent. That number is three times higher-33 per cent-for those businesses that collaborate with all three triple-helix actor categories.

Although only a minority of companies are involved in triple helix, these companies are at the same time among the most successful. Co-operation is thus far from being the last desperate way for a market actor to survive. There is a strong correlation between a company's economic growth and its involvement in triple helix co-operation. To conclude, the VINNVÄXT programme attracts successful companies with a high entrepreneurial profile. We can assume that at least part of the explanation is the good fit between the entrepreneurial management rationale of the programme and the sector orientation of the private companies. The way VINNVÄXT is run-placing emphasis on market focus and economic value maximisation and offering the competing regional partnerships a quasiautonomous position, in stark contrast to hierarchical decision-making processes and requirements on accountability reports-is clearly an attractive management solution for business companies.

\subsection{Public Sector Bodies Acting in a Vacuum}

Our next question is whether VINNVÄXT creates attractive conditions for public sector bodies and research institutes as well. Since triple helix co-operation is initiated and funded by the government, and managed by a government agency, VINNOVA, we may assume that the participation of public sectoral actors would be least problematic in comparison with other triple helix 
actors. Surprisingly, however, politicians and public agencies appear to meet serious obstacles in finding a proper way to contribute to the programme (Westerberg, 2009, p. 38). As a result, the role of regional government agencies, municipal councils and county governors is limited in triple helix collaborations. Politicians are also more active in the initial stages of the cooperation than during the later phases. The explanation the evaluation report offers is that the main competence of politicians is on a general level, concerning structural and financial questions, and that a lack of time and expertise results in a successively declining involvement in concrete triple helix project activities. In addition, not only politicians, but even civil servants, have too little knowledge about commerce and the conditions applicable to industry, which makes it hard for them to contribute to partnerships.

Is the source of the problem to be found in the mismatch between the highly entrepreneurial management rationale of the programme and the alternate value orientation of public sectoral actors? It is not immediately clear that this is the case. The lack of required knowledge in the area of expertise is not a direct consequence of the choice of management rationale. Yet, it is possible to argue that it is the responsibility of the overall collaboration management to create the working conditions, in terms of structure and decision-making processes, that enable all of the participating actors to contribute to the joint project, regardless of their sector backgrounds.

What about the third partner: research institutes and universities? In triple helix, research partners are expected to bring in the necessary knowledge for development of new products, innovations and technology. As we have seen, a high share of academics among the staff is positively correlated with a company's willingness to get involved in a cross-sectoral triple helix project. If the share of academics is a key factor, then hypothetically research institutes should be highly interested in joining triple helix. However, the report shows that their participation is severely hampered by the logics of the academic world. The meritocratic public sector principles of non-profit making do not travel well with the idea of triple helix: state-owned research institutes are not allowed to make economic profits on new market/industrial products. This is obviously an impediment to their participation in triple helix. Taken together, these results indicate that there is a mismatch between the entrepreneurial management rationale, with its market focus and possibilities to value maximisation, and the sector orientations of participants representing the public sector norms, values and working processes.

\section{Mismatch-Collaboration with Benefits and Barriers}

Today, great emphasis is placed on policy co-ordination that relies primarily on shared learning and socialisation. Pooling resources, capacities and competencies from both the business sector and public bodies in crosssectoral collaboration, such as in the EQUAL programme and the Swedish triple helix initiative, is expected to bring about beneficial synergy effects, economic growth and innovative job creation. Joint action promises to make the most of diverse sector competencies.

We have highlighted empirically the effects of management rationale on cross-sectoral collaboration in these two very different programmes: the first involving the EU multilevel process, aiming at implementing the European Employment Strategy (EES); the latter involving the implementing of Swedish regional policy. As shown in the summary of the empirical findings in Table 3 , the triple helix initiative VINNVÄXT, the main objective of which is to put into practice a government policy for regional economic growth, closely follows the entrepreneurial management rationale. EQUAL, in contrast, is in many regards strongly guided by a bureaucratic rationale.

VINNVÄXT, although a state initiative, is keen on the idea of profit maximisation - wishing to accomplish this at the national level by means of enhancing competition at the regional level by finding the best ways to maximise value on their own. With regards to its ideology, it could hardly resemble the entrepreneurial principles more than it does: efficiency is to be brought about by relying on competition as a central market mechanism. As concerns government control, this is limited since the cross-sectoral projects operate autonomously within the limits of existing legislation. Moreover, the entrepreneurial logic is manifested, as the initial participation in the joint effort in itself is not rewarded. Instead, economic incentives are linked to performance goals.

EQUAL, on the other hand, operates under the EU'S centralised and rule-based control. EU regulation takes the form of binding contracts and related funding of cross-sectoral activities. In terms of ideological position, the programme is explicitly based on the centrality of the EU directive, instead of state legislation, as would normally be the case. The system of regular activity reports is a central control mechanism, which stresses that partnerships are accountable for how they implement the EU programme directive.

The evaluation reports provide a more detailed picture of the structure and decision-making processes in EQUAL than in VINNVÄXT. Even though this might at first seem to be a methodological problem, it is also an essential empirical result: it tells us about important differences between these two programmes. Not only is it the case that the EU strictly regulates and monitors the working processes in EQUAL; it also provides rich public documentation covering the programme and its structure and decisions-making processes. We learn, for example, that the participatory forms of decision- 
Table 3. Management rationales of EQUAL and VINNVÄXT.

\begin{tabular}{|c|c|c|}
\hline & Bureaucratic & Entrepreneurial \\
\hline \multirow[t]{3}{*}{ Goals } & Implementing government policies, accountability & Value/profit maximisation \\
\hline & EQUAL: implementing EU programme/EES policy & VINNVÄXT: regional profit \\
\hline & VINNVÄXT: Swedish government policy & maximisation \\
\hline \multirow[t]{2}{*}{ Ideology } & Legislative order/state focus & Market/efficiency focus \\
\hline & EQUAL: EU directive focus & VINNVÄXT: efficiency by means of competition \\
\hline \multirow[t]{2}{*}{ Control } & Centralised/rule-based & $\begin{array}{l}\text { Quasi-centralised/incentives related to performance } \\
\text { goals }\end{array}$ \\
\hline & EQUAL: EU-centred, contract-based & $\begin{array}{l}\text { VINNVÄXT: the winning } \\
\text { collaboration receives a prize }\end{array}$ \\
\hline \multirow[t]{2}{*}{ Structure } & Hierarchical & Quasi-autonomous/delegation \\
\hline & EQUAL: regulated, top-down & VINNVÄXT: autonomous regional collaborating units \\
\hline \multirow{2}{*}{$\begin{array}{l}\text { Decision- } \\
\text { process }\end{array}$} & Top-down in accordance with government policies & Ad-hoc dictated by value maximisation \\
\hline & $\begin{array}{l}\text { EQUAL: top-down, centralised regulated and } \\
\text { monitored }\end{array}$ & VINNVÄXT: to identify the yearly prize winner \\
\hline
\end{tabular}

making initially used at the partnership level were later abandoned in favour of more centralised processes. In contrast, the most central decision in VINNVÄXT was the selection of the annual winner. Other than this, cross-sectoral collaborations operated autonomously from the government, with working processes being neither regulated nor monitored or documented in detail.

What, then, can we say about the effects of the mismatch, according to Table 4? How did EQUAL and VINNVÄXT perform in terms of recruiting relevant actors and guaranteeing sustainability of collaboration, given their divergent management rationales?

First, public bodies found it easier to adapt to the coercive top-down regulations and control in the EQUAL programme, which even involved a specific EU project terminology that was difficult to cope with for those who were not already used to it. This very rationale, however, deterred business companies from getting involved in the programme, and, moreover, the ones that participated found it difficult to maintain their participation throughout the contracted programme period. These results are well in line with research findings, according to which business actors with manifest economic interests sometimes tend not to make better partners, since their need to prioritise short-term returns on investments may conflict with a long-term perspective that is required to realise public policy targets (Koppenjan \& Enserink, 2009, p. 284). In brief, the mismatch had consequences for the performance of EQUAL, with it failing to recruit relevant actors or to guarantee sustainability in the collaboration.

The highly entrepreneurial management rationale of the Swedish government initiative VINNVÄXT, which is based on the legacy of co-operation between market actors and public bodies and which sees joint publicprivate action as necessary for opening access to new markets and new products, was, by contrast, attractive to business companies. In addition, the matching dispositions of market actors and the triple helix programme's entrepreneurial management rationale was also manifested in primarily attracting companies that are successful, have a strong entrepreneurial profile, have a propensity for risk taking and are provided with good resources. Companies that instead tend to abstain from cross-sectoral collaboration are often those with weaker entrepreneurial behaviour and lower economic growth.

There is also evidence of a mismatch between the entrepreneurial rationale and the orientation of public sector actors in VINNVÄXT: the public sector actors had difficulties in contributing to joint action after the initial stages of the collaboration as their limited knowledge of the conditions for the business sector and industry made it difficult for them to fully participate. An interesting question is, then, whether it is reasonable to re-

Table 4. Management rationale and mismatch in EQUAL and VINNVÄXT.

\begin{tabular}{|c|c|c|c|}
\hline \multicolumn{4}{|c|}{ Management rationale } \\
\hline & & Bureaucratic & Entrepreneurial \\
\hline \multirow{2}{*}{$\begin{array}{l}\text { Sector } \\
\text { orientation }\end{array}$} & $\begin{array}{l}\text { Public } \\
\text { body }\end{array}$ & Match & $\begin{array}{l}\text { Mismatch } \\
\text { VINNVÄXT }\end{array}$ \\
\hline & $\begin{array}{l}\text { Private } \\
\text { company }\end{array}$ & $\begin{array}{l}\text { Mismatch } \\
\text { EQUAL }\end{array}$ & Match \\
\hline
\end{tabular}


quire public agencies and politicians to possess that kind of knowledge and, if so, in how much detail? Is it possible to argue why should they? Indeed, in a neoWeberian state professionalisation of public services implies that a "bureaucrat" not only masters existing legislation in a given area of expertise but that he/she is also professional in terms of being able to meet the concrete needs of the users of public service (Pollitt \& Bouckaert, 2011, p. 119). To the extent that business companies and industry are considered to be users of public service, the answer is affirmative.

The participation of state-run research institutes is central to the Swedish triple helix initiatives. However, it also appeared to be somewhat problematic. The entrepreneurial management rationale, in that it stresses economic value maximisation, is not very compatible with meritocratic principles of state-owned research institutes/universities: being public sector bodies, their incentive structure does not allow economic gains, and nor does it encourage collaboration with private companies for that purpose.

\section{Concluding Discussion-Closing the Gap?}

In conclusion, while acknowledging the methodological limitations of the empirical study as it relies on secondary sources, the main findings suggest that the management rationale for cross-sectoral collaborationbureaucratic or entrepreneurial-is an important factor in the construction of successful and sustainable joint action. The present results lend some support to previous research, which indicate that an entrepreneurially oriented approach is associated with better performance, in terms of the capacity to recruit relevant actors and establish sustainable collaboration. In comparison with VINNVÄXT, EQUAL experienced more severe problems in attempting to engage relevant collaborators.

Diversity in cross-sectoral collaboration, while being not only constitutive of, but also associated with high innovation potential, can also become a constraining factor in terms of the mismatch between the overall management rationale and the sector orientations of the participants. This holds true, regardless of the management rationale-bureaucratic or entrepreneurial. In EQUAL, the mismatch occurs between the bureaucratic rationale and the orientation of the business actors, and in the Swedish VINNVÄXT programme, between the entrepreneurial rationale and public sector orientation of civil servants, politicians and state-run research institutes. In both cases the mismatch reduces the opportunities for some of the participants to fully contribute to the joint project. The opposite also holds true, i.e., when the management rationale coincides with the same-sector logic of a collaborator, the latter is more likely to make a positive contribution.

Differences in underlying sector appropriateness norms still play an important role. Not only do same- sector public-public collaborations perform better in terms of effectiveness than cross-sectoral ones, as earlier research indicates, the theory that same sector background has a positive effect is also valid on the next level, i.e., for the relationship between the management rationale and the sector background of the actor.

Finally, the empirical results raise an interesting question about whether it would be possible to overcome, or at least to regulate, the negative effects of mismatch and thereby secure the positive synergy effects of bringing together different sector competences, perspectives and knowledge. The question of how to close the mismatch gap is especially vital for practitioners and policy-makers.

What could management do about the mismatch? If the cause of the problem is defined as a lack of incentives for rational actors, calculating possible costs and benefits, to contribute, then one solution could be to adjust the incentive structure so that it more strongly favours co-operation. Conversely, if the organisational norms shaping the actions of participants and potential participants are seen as being be the main source of the problem, the solution is to influence the norms and role expectations of the actors. In VINNVÄXT, a solution for entrepreneurially oriented management could be to show special concern for public sector participants, perhaps by using economic incentives to empower them so that they become more knowledgeable about the workings of the private sector and could thereby more fully contribute to the collaboration. An alternative would be to alter their norms and role perceptions so that they see it as a legitimate requirement for modern public sector representatives, if not to be experts on, at least to be well informed about the conditions of business companies and industry. If the participation of research institutes is regarded as so crucial, a solution might be to stress the norm of social responsibility in the same manner that business companies adopt the imperative of corporate social responsibility. An alternative is to modify the incentive structure so that it better rewards them for collaboration with market actors.

The situation is somewhat different in the case of EQUAL. Since collaborators are already initially funded for their participation, it is less plausible that additional economic benefits, used as a means of changing the incentive structure for utility-maximising actors, would make any substantial difference in the willingness of business companies to participate. Here, the management could choose an alternative approach and see the problem as primarily caused by misperceptions on the part of business actors of proper role expectations. In this case, investing in norm building, by stressing the norm of corporate social responsibility and thereby creating greater acceptance for EQUAL's management rationale, for example, might be a possible direction which could be pursued. 


\section{Acknowledgements}

I wish to thank four anonymous reviewers for generous comments on previous drafts of this article.

\section{Conflict of Interests}

The author declares no conflict of interests.

\section{References}

Andrews, R., \& Entwistle, T. (2010). Does cross sectoral partnership deliver? An empirical exploration of public service effectiveness, efficiency, and equity. Journal of Public Administration Research and Theory, 20, 679-701.

Bernard Bruhnes International. (2006). EU-Wide Evaluation of the Community Initiative EQUAL 20002006, Final Report. Brussels, Belgium: DG Employment and Social Affairs.

Bernard Brunhes Internacional. (2009). Synthesis of the Evaluation Reports of the EQUAL Programme in the EUR-15 Member States 2009 Submitted to the Commission in 2007 and Up to June 2008. Brussels, Belgium: European Commission DG Employment and Social Affairs.

Bozeman, B., \& Bretschneider, S. (1994). The "publicness puzzle" in organization theory: A test of alternative explanations of differences between public and private organizations. The Journal Public Administration Research and Theory, 4(2), 197-224.

Bredgaard, T., \& Larsen. F. (2011). Implementing public employment policy: What happens when nonpublic agencies take over? International Journal of Sociology and Social Policy, 27(7-8), 287-300.

DiMaggio, P. (1988). Interest and Agency in Institutional Theory. In G. Zucker (Ed.), Institutional Patterns and Organizations, Culture and Environment. Cambridge: Harper \& Row.

Economix, Research \& Consulting. (2009). Synthesis of the Evaluation Reports of the EQUAL Programmes in the EU10 Member 2009 States Submitted to the Commission within 2006 and 2009. Brussels, Belgium: European Commission DG Employment, Social Affairs and Equal Opportunities.

European Commission. (2000). Communication from the Commission to the Member States. Establishing the Guidelines for the Community Initiative EQUAL (C2000 853). Brussels, Belgium: European Commission.

European Commission. (2009). Commission to the European Parliament, the Council, the Economic and Social Committee and the Committee of the Regions. A Shared Commitment for Employment (COM(2009)257). Brussels, Belgium: European Commission.

du Gay, P. (2000). In Praise of Bureaucracy: Weber, Or- ganisation, Ethics. London: SAGE Publications.

du Gay, P. (2005). The Values of Bureaucracy. Oxford: Oxford University Press.

Goodsell, C. T. (2005). The Bureau as Unit of Governance. In P. Du Gay (Ed.), The Values of Bureaucracy. Oxford: Oxford University Press.

Haahr, J. H. (2004). Open co-ordination as advanced liberal government. Journal of European Public Policy, 11(2), 209-230.

Hall, P., \& Montin, S. (2007). Governance Networks and Democracy at Regional and Local Level in Sweden (Working paper no. 9). Denmark: Centrum for Democratic Network Governance, Roskilde University.

Hartlapp, M. (2007). On enforcement, management and persuasion: Different logics of implementation policy in the EU and the ILO. Journal of Common Market Studies, 45(3), 653-674.

Hendriks, C. M. (2009). The democratic soup: Mixed meanings of political representation in governance networks. Governance, 22, 689-715.

Herranz, J. (2007). The multisectoral dilemma of network management. Journal of Public Administration Research and Theory, 3(18), 1-31.

Herranz, J. (2010). Multilevel performance indicators for multisectoral networks management. The American Review of Public Administration, 40(4), 445460.

Innes, J. E., \& Booher, D. E. (2003). Collaborative Policymaking: Governance through Dialogue. In M. A. Hajer \& H. Wagenaar (Eds.), Deliberative Policy Analysis. Understanding Governance in the Network Society. Cambridge: Cambridge University Press.

Koppenjan, J. F. M., \& Enserink, B. (2009). Publicprivate partnerships in urban infrastuctures: Reconciling private sector participation and sustainability. Public Administration Review, 69(2), 284-296.

March, J. G., \& Olsen, J. P. (1984). The new institutionalism: Organisational factors in political life. American Political Science Review, 78(3), 734-749.

March, J. G., \& Olsen, J. P. (2006). The Logic of Appropriateness. In M. Moran, M. Rein, \& E. R. Goodin (Eds.), The Oxford Handbook of Public Policy (pp. 289-308). Oxford: Oxford University Press.

Mosher, J. S., \& Trubek, D. M. (2003). Alternative approaches to governance in the EU: EU social policy and the European employment strategy. Journal of Common Market Studies, 41(1), 63-88.

Peters, B. G. (2010). The Politics of Bureaucracy. London and New York: Routledge.

Pollit, C., \& Bouckaert, G. (2011). Public Management Reform. A Comparative Analysis: New Public Management, Governance, and the Neo-Weberian State. Oxford and New York: Oxford University Press.

Ragin, C. C. (1997). The Comparative Method: Moving beyond Qualitative and Quantitative Strategies. 
Berkeley: University of California Press.

Ramboll, Euréval, \& SEOR. (2010). Evaluation of the Contribution of the ESF to EES. Final Report 2010. Brussels, Belgium: DG Employment, Social Affairs and Equal Opportunities.

Scott, R. (1995). Institutions and Organisations. London: SAGE Publications Ltd.

Scott, R. (2003). Organisations. Rational, Natural, and Open Systems. New Jersey: Prentice Hall.

Selsky, J. W., \& Parker, B. (2005). Cross-Sector partnerships to address social issues: Challenges to theory and practice. Journal of Management, 31(849S), 864.

Smismans, S. (2008). The European social dialogue in the shadow of hierarchy. Journal of Public Policy,
28(1), 161-180. doi:10.1017/S0143814X08000822.

Sörensen, E., \& Torfing, J. (2007). Theories of Network Governance. New York: Palgrave Macmillan.

Westerberg, U. (2008). Politiken, Offentlig Verksamhet: En av tre Parter i Samverkan-En Erfarenhetsstudie Inom VINNOVAs VINNVÄXT-program (VINNOVA Rapport VR 2008:08). Stockholm: VINNOVA.

Westerberg, U. (2009). The Public Sector-One of Three Collaborating Parties. A Study of Experiences from the VINNVÄXT Program (VINNOVA Report VR 2009:19). Stockholm: VINNOVA.

Ylinenpää, H., \& Westerberg, M. (2004). Tio frågor och svar om samverkan $i$ Småföretag (NUTEK No. 2004:10). Stockholm, Sweden: Verket för näringslivsutveckling.

\section{About the Author}

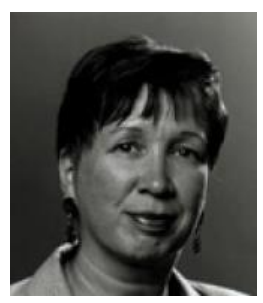

\section{Dr. Maritta Soininen}

Maritta Soininen is Professor at the Department of Political Science, University of Stockholm. Her research interests are public policy and policy governance. She also conducts research on political participation and political parties, primarily related to the field of migration and ethnic relations. Her research includes organisational analysis as well as comparative policy analysis. 